\title{
Hypophosphatemia and Rhabdomyolysis
}

\author{
J. P. Knochel, C. Barcenas, J. R. Cotton, T. J. Fuller, R. Haller, and \\ N. W. CARTER, Veterans Administration Hospital, Dallas, Texas 75216 and \\ The University of Texas Health Science Center at Dallas, Southwestern \\ Medical School, Dallas, Texas 75235
}

\begin{abstract}
A B S T RAC T Clinical observations suggest that overt rhabdomyolysis may occur if severe hypophosphatemia is superimposed upon a pre-existing subclinical myopathy. To examine this possibility, a subclinical muscle cell injury was induced in 23 dogs by feeding them a phosphorus- and calorie-deficient diet until they lost $30 \%$ of their original weight. To induce acute, severe hypophosphatemia in the animals after partial starvation, 17 of the dogs were given large quantities of the same phosphorus-deficient diet in conjunction with an oral carbohydrate supplement, which together provided $140 \mathrm{kcal} / \mathrm{kg}$ per day.
\end{abstract}

After phosphorus and caloric deprivation, serum phosphorus and creatine phosphokinase (CPK) activity were normal. Total muscle phosphorus content fell from $28.0 \pm 1.3$ to $26.1 \pm 2.5 \mathrm{mmol} / \mathrm{dg}$ fat-free dry solids. Sodium, chloride, and water contents rose. These changes resembled those observed in patients with subclinical alcoholic myopathy. When studied after 3 days of hyperalimentation, the animals not receiving phosphorus showed weakness, tremulousness, and in some cases, seizures. Serum phosphorus fell, the average lowest value was $0.8 \mathrm{mg} / \mathrm{dl}(P<0.001)$. CPK activity rose from $66 \pm 357$ to $695 \pm 1,288$ IU/liter $(P<0.001)$. Muscle phosphorus content fell further to $21.1 \pm 7.7$ $\mathrm{mmol} / \mathrm{dg}$ fat-free dry solids $(P<0.001)$. Muscle Na and $\mathrm{Cl}$ contents became higher $(P<0.01)$. Sections of gracilis muscle showed frank rhabdomyolysis.

6 of the 23 phosphorus- and calorie-deprived dogs were also given $140 \mathrm{kal} / \mathrm{kg}$ per day but in addition, each received $147 \mathrm{mmol}$ of elemental phosphorus. These dogs consumed their diet avidly and displayed no symptoms. They did not become hypophosphatemic, their CPK remained normal, and derangements of cellular $\mathrm{Na}, \mathrm{Cl}$, and $\mathrm{H}_{2} \mathrm{O}$ were rapidly corrected. The gracilis muscle appeared normal histologically in these animals.

\footnotetext{
Presented at plenary session of the Annual Meeting of the Association of American Physicians, San Francisco, Calif., April 1978.

Received for publication 12 May 1978 and in revised form 17 July 1978.
}

These data suggest that a subclinical myopathy may set the stage for rhabdomyolysis if acute, severe hypophosphatemia is superimposed. Neither acute hypophosphatemia nor rhabdomyolysis occur if abundant phosphorus is provided during hyperalimentation.

\section{INTRODUCTION}

Recent observations have shown that most severe alcoholics with either clinical or laboratory evidence of alcoholic myopathy have abnormally low total phosphorus content in skeletal muscle (1). Many of these patients demonstrate normal or slightly subnormal values for serum phosphorus concentration. when they are admitted to the hospital. However, during the first few hospital days, hypophosphatemia appears and may become progressively more severe. It generally occurs as nutrients are administered and from all evidence, results from phosphorus movement into cells (2). At least in some patients, this decline of serum phosphorus is associated with a sharp rise of serum creatine phosphokinase (CPK) ${ }^{1}$ activity (1), suggesting that severe hypophosphatemia may be responsible for converting a subclinical myopathy into acute rhabdomyolysis.

In previous reports, we have shown an abnormally low total phosphorus content of muscle tissue in patients with alcoholic myopathy. They also demonstrated elevated muscle content of sodium, chloride, and water. Directly measured transmembrane electrical potential difference of skeletal muscle cells was abnormally low (1). Such abnormalities suggest a defect in ion transport. Subsequent studies in dogs (3) showed that experimental phosphorus deficiency led to weakness, anorexia, and an electrochemical disturbance of muscle cells closely resembling that observed in patients with alcoholic myopathy. This was reversible upon phosphorus repletion. Of interest, hypophosphatemia developed gradually and did not become severe in these experimental animals. In addition, CPK activity re-

${ }^{1}$ Abbreviations used in this paper: CPK, creatine phosphokinase; FFDS, fat-free dry solids. 
mained within normal limits despite chemical derangements of the muscle cells. These features were quite similar to our observations on patients with alcoholic myopathy before they developed severe hypophosphatemia (1). Therefore, whereas simple phosphorus deficiency may lead to a subclinical cellular injury, the development of acute rhabdomyolysis may require superimposition of an additional insult, such as hypophosphatemia.

The purpose of this study was to determine if hypophosphatemia induced by hyperalimentation can produce acute rhabdomyolysis in the dog if it is superimposed upon an existing electrochemical injury. A subclinical myopathy was induced by phosphorus deprivation and partial starvation so that severe hypophosphatemia would likely occur upon re-feeding without phosphorus. The results show that administration of excessive calories to an animal prepared in this manner causes severe hypophosphatemia and acute rhabdomyolysis. Such hyperalimentation in the same animal preparation causes neither hypophosphatemia nor rhabdomyolysis if adequate elemental phosphorus is provided in the diet.

\section{METHODS}

The dog model used in these studies was developed to stimulate certain features of severe, chronic alcoholics found to have myopathy. These patients commonly have lost body weight and are phosphorus deficient.

23 healthy male mongrel dogs weighing from 22 to $25 \mathrm{~kg}$ were each studied on three occasions: $(a)$ control, $(b)$ after weight loss and phosphorus deprivation, and $(c)$ after hyperalimentation with and without supplemental phosphorus. Control studies were conducted after the animals had received a synthetic, phosphorus-deficient but otherwise nutritionally adequate diet for 7 days. Before the control study, $1.87 \mathrm{~g}$ of $\mathrm{Na}_{2} \mathrm{HPO}_{4}$ was added to the diet each day. The diet was obtained from ICN Pharmaceuticals Inc., Life Sciences Group, Cleveland, Ohio. Each 100 g contained 410 calories, $20 \mathrm{~g}$ of protein, $60 \mathrm{~g}$ of carbodhydrate, and $10 \mathrm{~g}$ of fat. Upom chemical analysis, each $100 \mathrm{~g}$ of diet contained $26 \mathrm{mg}$ of elemental phosphorus, $3 \mathrm{mmol}$ of magnesium, and $36 \mathrm{meq}$ of potassium. In other respects the diet contained all vitamins, minerals, and electrolytes in excess of minimum requirements. For the control study, sufficient diet was fed to provide 30 calories $/ \mathrm{kg}$ per day. On day 8 , when the dogs were under sedation with $15 \mathrm{mg} / \mathrm{kg}$ body wt pentobarbital, serum CPK, plasma and muscle sodium, potassium, chloride, and total phosphorus were measured. Venous blood was also sampled for $\mathrm{pH}$, carbon dioxide tension, and oxygen tension. For determination of composition, samples of the gracilis muscle were collected with a needle biopsy instrument and analyzed as previously described $(3,4)$.

After the control study, the dogs were placed on the same synthetic diet without added phosphorus but in a reduced quantity to provide 15 calories/kg per day. Aluminum carbonate gel (Basaljel, Wyeth Laboratories, Philadelphia, Pa.), $60 \mathrm{ml}$, was mixed into the diet each day to bind phosphorus in the gut. The dogs were weighed daily before feeding. The second study, identical to the first, was conducted when the animals had lost $30 \%$ of their initial body weight.

After the effects of weight loss and phosphorus deprivation were determined, 17 of the animals were begun on $500 \mathrm{~g}$ of the same diet without added phosphorus but with sufficient added carbohydrate to provide 140 calories $/ \mathrm{kg}$ per day. The extra carbohydrate was provided as a solution that contained $10 \mathrm{~g}$ glucose and $40 \mathrm{~g}$ of maltose $/ 100 \mathrm{~cm}^{3}$. One-half of the diet was given in the morning and one-half in the afternoon. Any diet not consumed spontaneously was fed by gavage. The remaining six dogs were fed the same diet without aluminum carbonate. This diet contained phosphorus and provided 140 calories/kg per day. Because both hypophosphatemia and hypokalemia may occur under conditions of such hyperalimentation, sodium and potassium phosphate were administered in the following proportions: $3 \mathrm{mmol} \mathrm{Na}_{2} \mathrm{HPO}_{4}$, $8 \mathrm{mmol} \mathrm{NaH}_{2} \mathrm{PO}_{4}, 3 \mathrm{mmol} \mathrm{K}_{2} \mathrm{HPO}_{4}$, and $3.2 \mathrm{mmol} \mathrm{KH}_{2} \mathrm{PO}_{4} .20 \mathrm{~g}$ of this mixture was given to each dog daily. This quantity contained $147 \mathrm{mmol}$ of phosphorus and $79 \mathrm{meq}$ of potassium. This quantity contained $147 \mathrm{mmol}$ of phosphorus and $79 \mathrm{meq}$ of potassium. Fasting blood samples were collected on each morning during hyperalimentation. Skeletal muscle was obtained $72 \mathrm{~h}$ after initiation of hyperalimentation unless the animal appeared seriously ill before that time. For the same reason, some dogs were biopsied on the 2 nd or 3 rd day of hyperalimentation. For examination of muscle histology, stretched sections of gracilis muscle were removed, fixed in buffered formalin, and stained with hematoxylin and cosin.

Serum sodium, potassium, and chloride determinations were performed by conventional laboratory procedures. Serum phosphorus was measured by the colorimetric method used for the Technicon AutoAnalyzer (Technicon Instruments Corp., Tarrytown, N. Y.). Muscle sodium, chloride, and potassium contents were determined on dilute acetic acid extracts of dried, fat-extracted samples that weighed $10-20 \mathrm{mg}$ as previously described (4). Serum CPK activity was measured spectrophotometrically by a modification of the Rosalki procedure (5). After weight loss and hyperalimentation electrolytes and total phosphorus in muscle were compared individually to their respective values obtained during the control study by the paired $t$ test. All data are expressed as mean \pm 1 SD.

\section{RESULTS}

As noted previously, dogs fed a phosphorus-deficient diet generally became anorectic and had to be gavage fed when the diet was not voluntarily consumed. Except for equivocal weakness and diminished spontaneous physical activity, the animals displayed no unusual symptoms during the period of caloric deprivation. From 28 to 40 days were required for the dogs to lose $30 \%$ of their initial weight. During the period of hyperalimentation those not given a phosphorus supplement became extremely ill. They demonstrated tremulousness, difficulty in standing, and severe weakness. Some displayed convulsive movements. Four died by the 3rd day of hyperalimentation. Data on these animals were excluded.

Individual values for serum phosphorus concentration are shown in Fig. 1. The average value in the control study was $4.4 \pm 0.8 \mathrm{mg} / \mathrm{dl}$. After the dogs received the phosphorus-deficient diet and lost $30 \%$ of their original body weight, the serum phosphorus was $3.9 \pm 1.2 \mathrm{mg} / \mathrm{dl}$. This was not significantly different from the control value. After 3 days of hyperalimentation, 

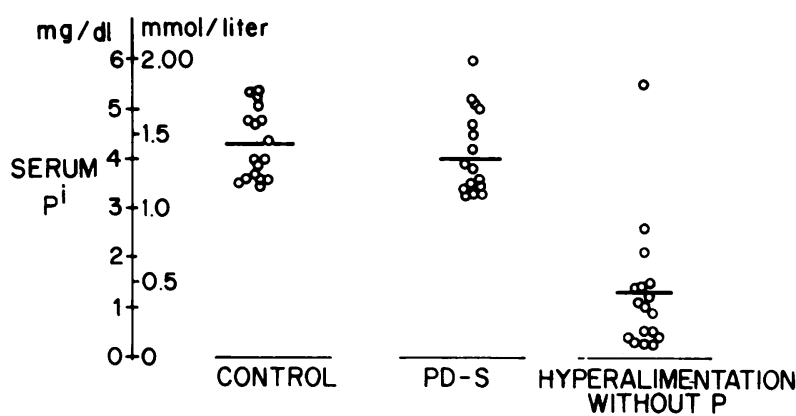

FIGURE 1 Serum phosphorus concentration before and after phosphorus deprivation and starvation (PD-S) and after hyperalimentation without supplemental phosphorus.

the average value was $1.2 \pm 1.3 \mathrm{mg} / \mathrm{dl}(P<0.001)$. The average lowest value observed during the 3 days of hyperalimentation was $0.8 \pm 0.6 \mathrm{mg} / \mathrm{dl}$. One animal showed a serum phosphorus of $5.6 \mathrm{mg} / \mathrm{dl}$. This $\mathrm{dog}$ was extremely ill and before death had a serum urea nitrogen above $100 \mathrm{mg} / \mathrm{dl}$. Its urine showed heme positive pigment which was presumably myoglobin.

Serum CPK activity is shown in Fig. 2. Before caloric deprivation, CPK averaged $52 \pm 22 \mathrm{IU} / \mathrm{ml}$. After weight loss and the phosphorus-deficient diet, CPK activity averaged $66 \pm 357 \mathrm{IU} / \mathrm{ml}$. These values were not significantly different. However, hyperalimentation without supplemental phosphorus was associated with a broad range of elevated CPK values in 14 of 17 animals. The average highest value was $695 \pm 1,288 \mathrm{IU} / \mathrm{ml}$. The isolated value of $5,470 \mathrm{IU} / \mathrm{ml}$ was observed in the same dog that showed hyperphosphatemia, azotemia, and evidence of myoglobinuria. Kidney tissue was not examined.

Total phosphorus content of skeletal muscle is shown

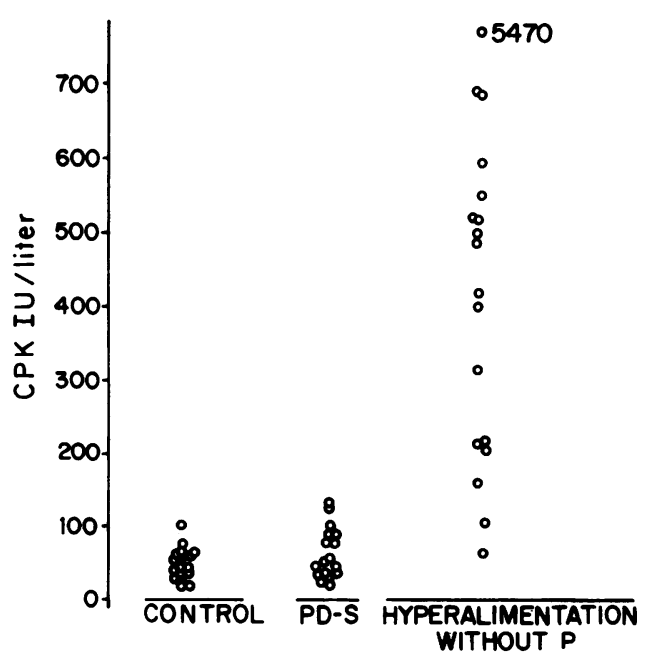

FIGURE 2 Serum CPK activity before and after phosphorus deprivation and starvation (PD-S) and after hyperalimentation without supplemental phosphorus.

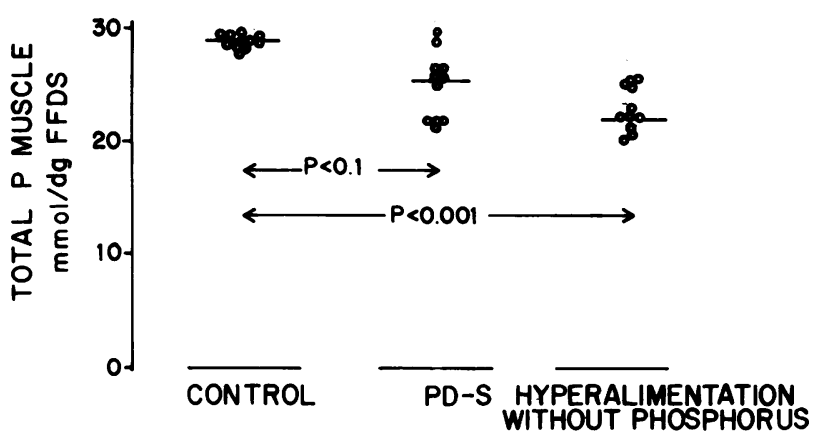

Figure 3 Total muscle phosphorus (P) content before and after phosphorus deprivation and starvation (PD-S) and after hyperalimentation without supplemental phosphorus.

in Fig. 3. In the control period, total phosphorus averaged $28.0 \pm 1.3 \mathrm{mmol} / 100 \mathrm{~g}$ fat-free dry solids (FFDS). After the caloric-deficient diet without phosphorus, average muscle phosphorus was $26.1 \pm 2.5 \mathrm{mmol} / \mathrm{dg}$ FFDS. This value was significantly different from control $(P<0.01)$. Two animals showed a normal value for muscle phosphorus content. After hyperalimentation, muscle phosphorus declined moderately and averaged $21.1 \pm 7.7 \mathrm{mmol} / \mathrm{dg}$ FFDS $(P<0.001)$.

Muscle potassium, sodium, chloride, and water are shown in Fig. 4. Potassium content averaged 44.1 \pm 2.4 meq/dg FFDS in the control study. After weight loss and phosphorus deprivation, potassium averaged $44.6 \pm 1.9 \mathrm{meq} / \mathrm{dg}$ FFDS. After hyperalimentation, muscle potassium fell slightly to $40.3 \pm 4.9 \mathrm{meq} / \mathrm{dg}$ FFDS $(P<0.01)$. Hypokalemia did not occur. Muscle sodium content rose from $10.2 \pm 1.1$ to $13.5 \pm 4.2 \mathrm{meq} /$ dg FFDS after weight loss and phosphorus deprivation. After hyperalimentation, sodium rose further to $16.1 \pm 9.9 \mathrm{meq} / \mathrm{dg}$ FFDS. This value was significantly
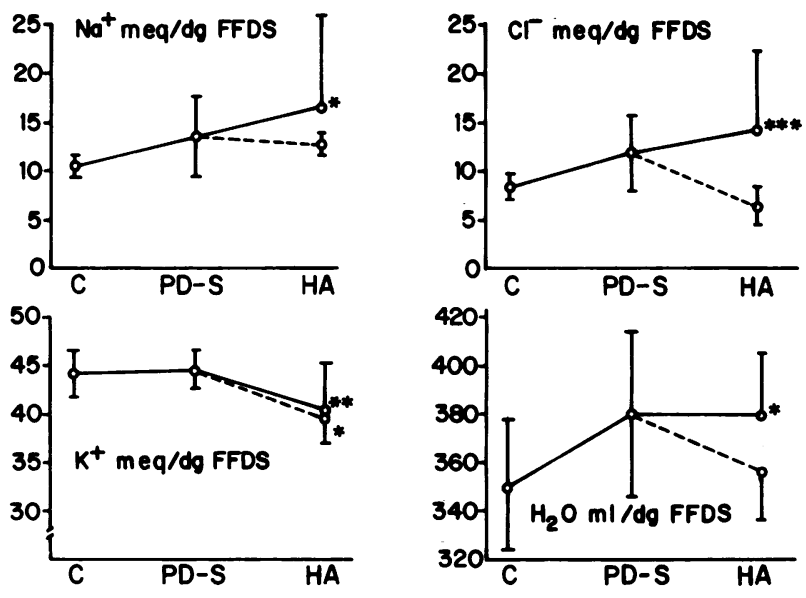

Figure 4 Muscle $\mathrm{Na}, \mathrm{Cl}, \mathrm{K}$, and water content before and after partial starvation and phosphorus deprivation (PD-S), after hyperalimentation without phosphorus $(\mathrm{O}-\mathrm{O})$, and after hyperalimentation with phosphorus $(O---O) .^{*}, P$ $<0.05$; ${ }^{* *}, P<0.01$; $^{* * *}, P<0.001$. 
different from control $(P<0.05)$ but not different from the value measured after caloric deprivation. After caloric and phosphorus deprivation, muscle chloride content rose from $8.3 \pm 9.3$ to $11.9 \pm 3.9 \mathrm{meq} / \mathrm{dg}$ FFDS. This was not significantly different from that determined in the control period. However, after hyperalimentation, chloride rose further and averaged 14.1 \pm 8.4 meq/dg FFDS. This was significantly different from the control value $(P<0.001)$ but not from that established after caloric deprivation. Muscle water content rose from $351 \pm 27$ to $380 \pm 34 \mathrm{ml} / \mathrm{dg}$ FFDS after caloric deprivation. After hyperalimentation, water remained essentially unchanged at $379 \pm 26 \mathrm{ml} / \mathrm{dg}$ FFDS. This was also significantly different from control $(P<0.05)$ but not significantly different from that determined after caloric deprivation.

In sharp contrast to dogs not given a phosphorus supplement, those that received a phosphorus supplement during hyperalimentation avidly consumed their diets and appeared healthy. Despite an intake of 147 mmol of elemental phosphorus daily, there was no diarrhea. Hypophosphatemia did not occur (Fig. 5). In these dogs, average serum phosphorus after 3 days of hyperalimentation was $3.6 \pm 0.7 \mathrm{mg} / \mathrm{dl}$. This is markedly different from the lowest average of $0.8 \pm 0.6$ $\mathrm{mg} / \mathrm{dl}$ in the dogs not receiving phosphorus supplements during hyperalimentation.

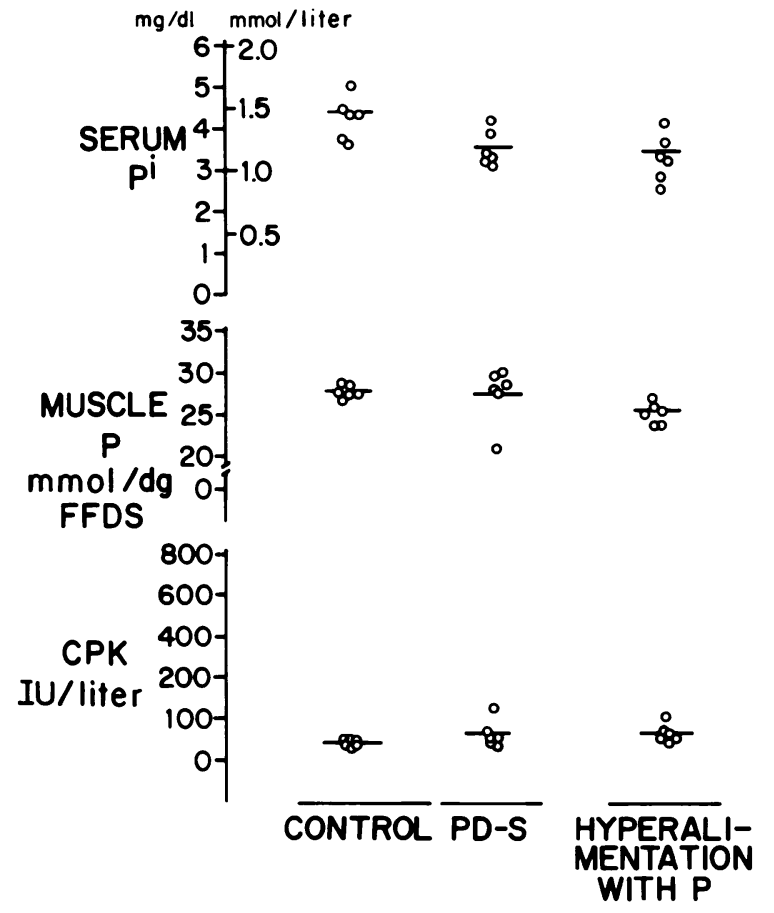

FIGURE 5 Serum phosphorus, muscle phosphorus, and serum CPK activity before and after phosphorus deprivation and starvation (PD-S) and after hyperalimentation with supplemental phosphorus.
Muscle phosphorus content after 3 days of hyperalimentation and phosphorus supplementation was $25.3 \pm 3.3$ $\mathrm{mmol} / \mathrm{dg}$ FFDS. This value was not significantly different from control. CPK activity also remained normal. Sodium, chloride, and water content of skeletal muscle in the six dogs hyperalimented and supplemented with phosphorus rapidly returned to normal (Fig. 4). These events stand in contrast to the climbing sodium and chloride content of muscle in dogs hyperalimented without supplemental phosphorus. Similar to animals re-fed without phosphorus, muscle potassium remained slightly below the control value, $39.7 \pm 3.7$ $\mathrm{meq} / \mathrm{dl}$ FFDS. This was significantly different from control $(P<0.05)$ but not different from the dogs refed without phosphorus. Surprisingly, the slightly low potassium content in skeletal muscle of the dogs re-fed with the phosphorus supplement persisted despite an average potassium intake of $250 \mathrm{meq} / \mathrm{day}$. Histologically, skeletal muscle showed gross rhabdomyolysis in partially starved dogs hyperalimented without phosphorus (Fig. 6). In those dogs hyperalimented with supplemental phosphorus, the muscle appeared normal (Fig. 7).

\section{DISCUSSION}

These studies show that phosphorus deprivation and partial starvation induce a subtle chemical injury of muscle cells characterized by a decline of total phosphorus and elevated content of sodium, chloride; and water. These findings are similar to those we have observed in chronic, severe alcoholics (1). Under both sets of circumstances, serum phosphorus concentration is generally normal or only moderately depressed and serum CPK activity is usually normal or only slightly elevated. In either severe alcoholics or dogs as prepared in these studies, administration of nutrients leads to hypophosphatemia. This is often followed by an abrupt rise of CPK activity. As illustrated by these studies, the rise of CPK activity is associated with histologic evidence of frank rhabdomyolysis.

The experimental model employed in these studies resembles acute hypophosphatemic rhabdomyolysis in man. Our observations suggest that hypophosphatemia per se and not hyperalimentation triggered rhabdomyolysis. This is supported by the observation that providing enough phosphorus in the diet to prevent hypophosphatemia during identical hyperalimentation prevents rhabdomyolysis. Indeed, adequate phosphorus supplementation during hyperalimentation rapidly corrected abnormal accumulations of sodium, chloride, and water in muscle tissue. In these hyperalimented, phosphorus-supplemented animals, the skeletal muscle appeared normal by light microscopy. The apparent inverse relationship between hypophosphatemia and elevated CPK activity is shown in Fig. 8. 


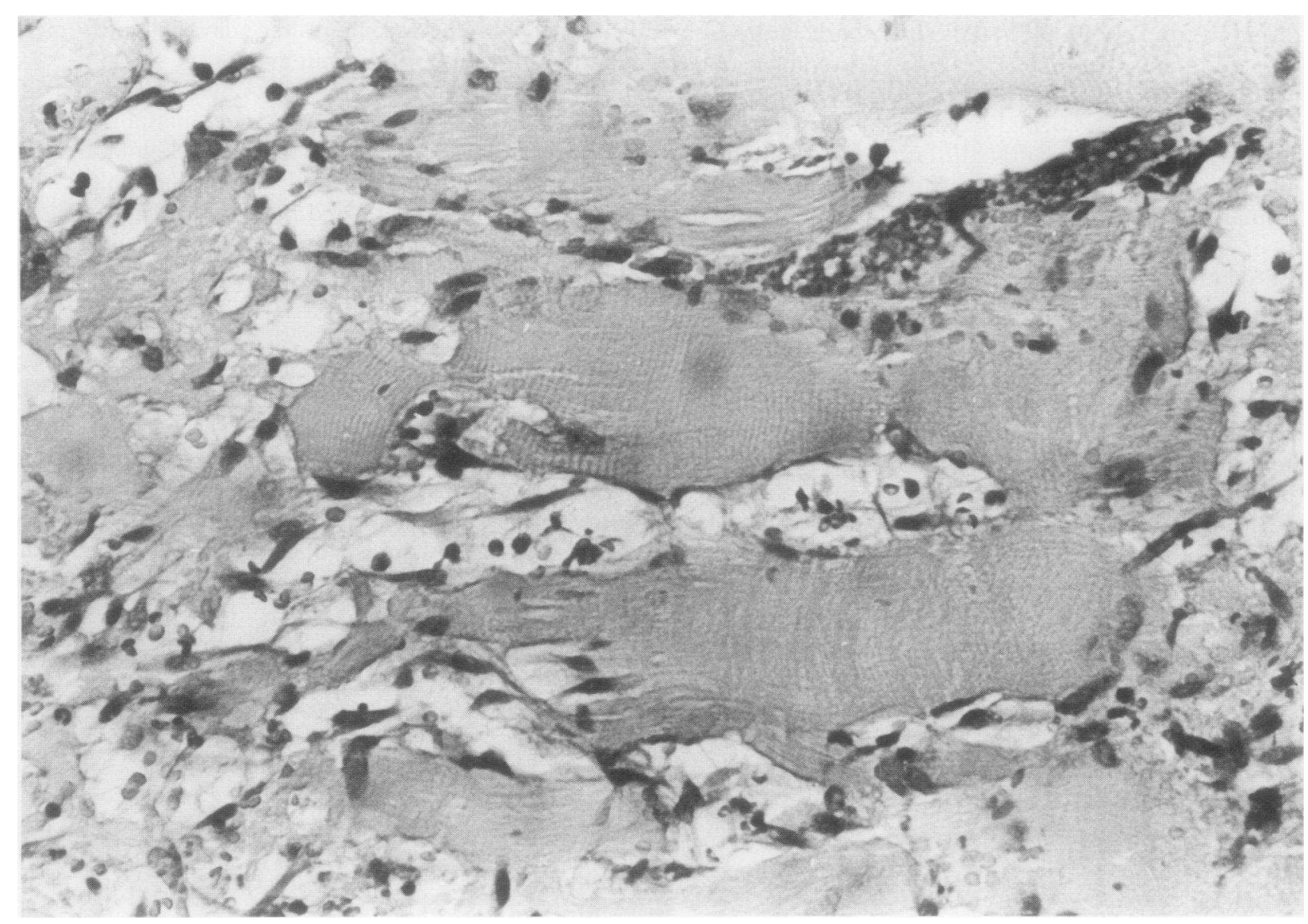

FIgURE 6 The light microscopic appearance of gracilis muscle from a partially starved dog hyperalimented without phosphorus. The muscle fibers are grossly distorted, hemorrhagic, and infiltrated by round cells and polymorphonuclear leukocytes. Some residual cross-striations remain in the center fiber $(\times 600)$.

Plotted in this manner, the data suggest that CPK activity becomes elevated only when serum phosphorus falls below $1.5-2.0 \mathrm{mg} / \mathrm{dl}$.

In addition to hypophosphatemia, phosphorus deficiency in muscle could have also contributed to the precipitation of acute rhabdomyolysis. In our previous studies of phosphorus-deficient dogs in which CPK was normal, total muscle phosphorus averaged $22.4 \mathrm{mmol} / \mathrm{dg}$ FFDS. In our current studies, muscle phosphorus averaged $21.1 \mathrm{mmol} / \mathrm{dg}$ FFDS. Although these values are nearly the same, it is possible that the rate at which muscle phosphorus fell in the hyperalimented dogs might have been an important factor underlying the sudden appearance of rhabdomyolysis.

The biochemical basis for cellular injury in hypophosphatemia may be severe depletion of ATP content (6). When phosphorus supplies are inadequate in the face of rapid cellular phosphorus uptake, hypophosphatemia results. Because inorganic phosphorus is in diffusion equilibrium across the plasma membrane
(7), intracellular phosphorus would also fall. Abundant evidence suggests that a severe decline of inorganic phosphorus inside the cell interferes with regeneration of ATP from ADP. In turn, a low concentration of intracellular inorganic phosphorus activates AMP deaminase and the decline of ATP activates 5'-nucleotidase. The result is a critical loss of adenylic acids and in effect, an elimination of energy supplies within the cell. Such events have been reported in the brain (8), leukocytes (9), platelets, and erythrocytes (10). Whether or not such phenomena occur in muscle cells as a result of hypophosphatemia and precede rhabdomyolysis has not been examined.

Physical exertion could have also played a role in rhabdomyolysis in these dogs. Thus, tremors and, in some instances, convulsive movements were common in severely hypophosphatemic animals. That physical activity and especially convulsive seizures may produce rhabdomyolysis and myoglobinuria is widely known (11). Moreover, they are especially apt to cause 


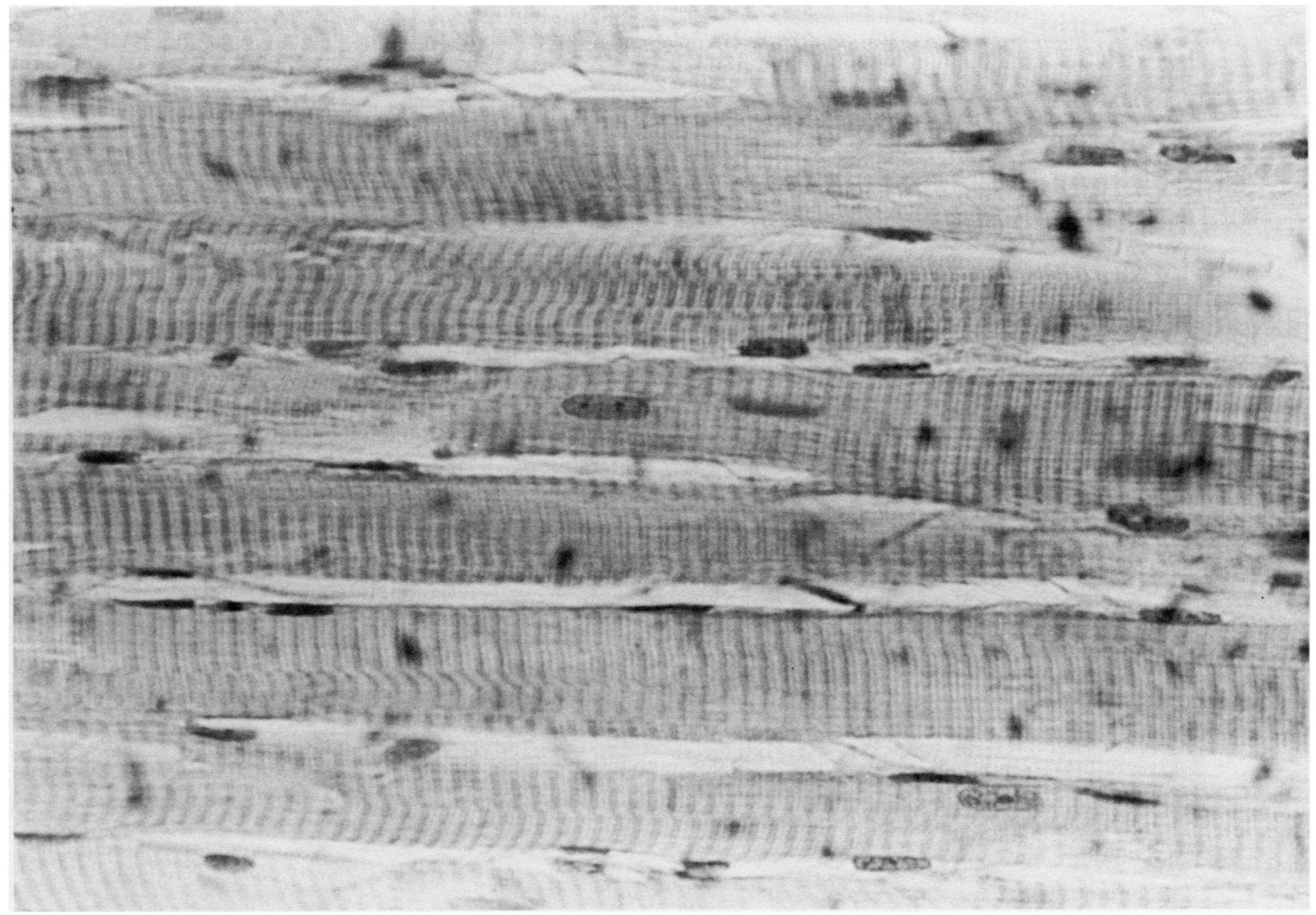

FIGURE 7 Histologic appearance of gracilis muscle taken from a partially starved dog after hyperalimentation with supplemental phosphorus. The muscle appears normal $(\times 600)$.

rhabdomyolysis if a myopathy already exists. Acute hypophosphatemia has been shown to cause convulsive seizures in both men (12) and experimental animals (8). In most instances hypophosphatemia had developed

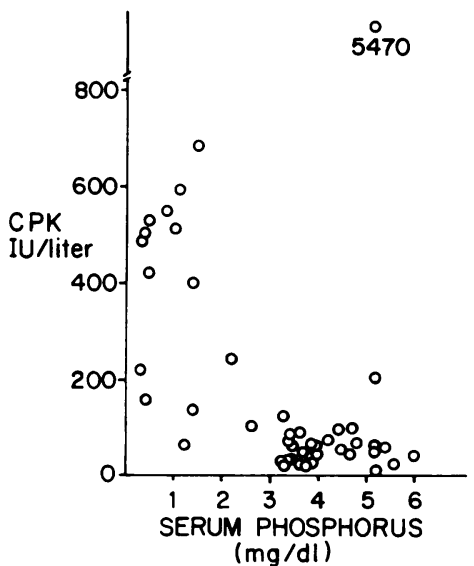

FIGURE 8 Comparison of serum CPK activity and serum phosphorus concentration. over the course of 1-10 days as nutrients were administered to either man or animals that previously had lost body weight $(9,10)$. Although comparably severe hypophosphatemia can be readily induced by respiratory alkalosis (13), to our knowledge this of itself has not been associated with acute rhabdomyolysis.

Potassium deficiency can also cause rhabdomyolysis $(14,15)$. Muscle potassium content falls slightly in otherwise well nourished phosphorus-deficient dogs (3). As demonstrated in these studies, it also remained in the lower range of normal in undernourished, phosphorus-deprived dogs after hyperalimentation with or without phosphorus supplements. However, hypokalemia did not occur and the decline of muscle potassium content was not severe. Based upon experimental (14) and clinical (15) observations, such a slight fall in muscle potassium would not ordinarily cause rhabdomyolysis.

\section{ACKNOWLEDGMENTS}

The authors express their gratitude to Donna Brese, James Long, D. L. Morris, and Patti Line for their help in this project. 
This work was supported by research funds from the United States Veterans Administration and the National Institute on Alcohol Abuse and Alcoholism, grant 1 ROl AA 02970-01.

\section{REFERENCES}

1. Knochel, J. P., G. L. Bilbrey, T. J. Fuller, and N. W. Carter. 1975. The muscle cell in chronic alcoholism. The possible role of phosphate depletion in alcoholic myopathy. Ann. N. Y. Acad. Sci. 252: 274-286.

2. Knochel, J. P. 1977. The pathophysiology and clinical characteristics of severe hypophosphatemia. Arch. Intern. Med. 137: 203-220.

3. Fuller, T. J., N. W. Carter, C. Barcenas, and J. P. Knochel. 1976. Reversible changes of the muscle cell in experimental phosphorus deficiency. J. Clin. Invest. 57: 10191024.

4. Bilbrey, G. L., N. W. Carter, M. G., White, and J. P. Knochel. 1973. Potassium deficiency in chronic renal failure. Kidney Int. 4: 423-430.

5. Rosalki, S. B. 1967. An improved procedure for serum creatine phosphokinase determination. J. Lab. Clin. Med. 69: 696-705.

6. Farber, E. 1973. ATP and cell integrity. 1973. Fed. Proc. 32: $1534-1539$.

7. Woods, H. F., L. V. Eggleston, and H. A. Krebs. The cause of hepatic accumulation of fructose-1-phosphate on fructose loading. Biochem. J. 119: 501-510.

8. Yawata, Y., P. Craddock, R. Hebbel, and H. S. Jacob. 1973.
Hyperalimentation hypophosphatemia: Hematologic neurologic dysfunction due to ATP depletion. Clin. Res. 31 : 729.

9. Craddock, P. R., Y. Yawata, L. Van Santen, S. Gilberstadt, S. Silvis, and H. S. Jacob. 1974. Acquired phagocyte dysfunction: A complication of the hypophosphatemia of parenteral hyperalimentation. N. Engl.J. Med. 290: 1403.

10. Yawata, Y., R. P. Hebbel, S. Silvis, R. Howe, and H. S. Jacob. 1974. Blood cell abnormalities complicating the hypophosphatemia of hyperalimentation: Erythrocytes and platelet ATP deficiency associated with hemolytic anemia and bleeding in hyperalimented dogs. J. Lab. Clin. Med. 84: 643-653.

11. Rowland, L. P., and A. S. Penn. 1972. Myoglobinuria. Symposium on Clinical Neurology. Med. Clin. N. Am. 56: 1233-1256.

12. Silvis, S. E., and P. D. Paragas. 1972. Paresthesias, weakness, seizures and hypophosphatemia in patients receiving hyperalimentation. Gastroenterology. 62: 513-520.

13. Mostellar, M. E., and E. P. Tuttle, Jr. 1964. The effects of alkalosis on plasma concentration and urinary excretion of inorganic phosphate in man. J. Clin. Invest. 43: 138-149.

14. Knochel, J. P., and E. M. Schlein. 1972. On the mechanism of rhabdomyolysis in potassium depletion. J. Clin. Invest. 51: 1750-1758.

15. Knochel, J. P. 1978. Rhabdomyolysis and effects of potassium deficiency on muscle structure and function. Cardiovasc. Med. 3: 247-261. 